\title{
Produksi Susu Induk Terhadap Pengaruh Pertambahan Bobot Badan, Bobot Sapih Dan Daya Hidup Anak Domba Ekor Tipis Jawa Periode Prasapih
}

\author{
The Effects of Milk Production of The Javanese Thin Tail on Average Daily Gain, \\ Weaning Weight and Survival of Pre-weaning Lamb \\ Jarmuji \\ Jurusan Peternakan, Fakultas Pertanian Universitas Bengkulu \\ Jl.Raya Kandang Limun, Bengkulu 38126, Email: Jarmuji78@yahoo.com
}

\begin{abstract}
The objectives of this research were to know the effect of milk yield on average daily gain, weaning weight and survival of pre- weaning lamb. This research was done in The Jonggol Animal Science Teaching, and Research Unit (JASTRU) located in Singasari Village, Jonggol, Bogor district from June to November 2007. One hundred local sheep comprises of pregnant and lactating ewes on average 3-5 years old were used in this research. The sheeps were grazed from 9 a.m. to 4 p.m. and housed at night. The result showed that milk yield significantly effect lamb average daily gain, weaning weight on two month and survival pre weaning period. Male lambs had higher average daily gain, weaning weight and survival compared to the female ones.
\end{abstract}

Key words : ewes, lamb, milk yield, weaning weight.

\section{ABSTRAK}

Penelitian bertujuan untuk mengetahui pengaruh produksi susu induk terhadap pertambahan bobot badan, bobot sapih dan daya hidup anak domba ekor tipis Jawa periode pra-sapih. Penelitian dilakukan di Unit Penelitian dan Pengajaran Ternak Jonggol (JASTRU), Desa Singasari, Jonggol Bogor tahun 2007. Domba yang digunakan adalah sebanyak 100 ekor dalam keadaan bunting dan laktasi yang berumur rata-rata 3-5 tahun. Domba dilepas untuk grazing dari pukul 9 hingga 16 dan malamnya dikandangkan. Hasil penelitian menunjukkan bahwa produksi susu secara nyata berpengaruh terhadap pertambahan berat badan, berat sapih pada 2 bulan dan daya hidup pra-sapih. Domba jantan memiliki rata-rata pertambahan berat badan, berat sapih dan daya hidup yang lebih tinggi dari pada betina.

Kata kunci: domba betina, domba, produksi susu, berat sapih.

\section{PENDAHULUAN}

\section{Bangsa-bangsa ternak lokal}

perlu dilindungi dan dipertahankan, karena memiliki beberapa keunggulan seperti kemampuan hidup dengan pakan kualitas rendah dan tekanan iklim setempat, serta lebih tahan terhadap penyakit dan parasit lokal (FAO, 2002). Domba lokal merupakan salah satu sumber daya genetik ternak yang berpotensi dikembangkan dalam penyediaan daging nasional. Domba lokal memiliki beberapa keunggulan di antaranya kemampuan dalam melahirkan anak kembar dua ekor atau lebih, umur dewasa kelamin relatif cepat serta tidak mengenal musim kawin sehingga dapat beranak sepanjang tahun. Domba lokal pada dasarnya digolongkan menjadi dua yaitu domba ekor tipis dan ekor gemuk.

Domba lokal memiliki siklus reproduksi yang cepat, dengan jarak kelahiran delapan bulan maka dalam 
dua tahun seekor induk domba sedikitnya menghasilkan tiga ekor anak pada kelahiran tunggal atau 1,5 ekor anak per induk pertahun. Namun kondisi ini masih dihadapkan pada masalah kurangnya daya tahan hidup anak domba yang dilahirkan per induk dalam mencapai usia sapih, terutama yang dilahirkan kembar dua atau lebih dengan tingkat kematian mencapai 40$60 \%$ (Iniquez et al., 1993). Angka kematian yang tinggi sebelum mencapai umur sapih ini sebagian besar disebabkan oleh kurangnya zat makanan yang disediakan oleh induk dalam bentuk air susu. Sementara anak domba sangat tergantung pada ketersediaan air susu sebagai bahan makanan dalam menopang pertumbuhan dan kehidupan sebelum ternak disapih. Produksi susu induk yang rendah juga dapat menurunkan laju pertumbuhan dan bobot sapih. Domba yang memiliki bobot sapih rendah dapat menurunkan kemampuan dalam bersaing memperoleh hijauan yang berkualitas di padang penggembalaan, sehingga pertumbuhan mencapai dewasa menjadi lambat dan menurunkan kemampuan reproduksi.

Populasi domba dapat ditingkatkan dengan cara memperbaiki produktivitas induk melalui kemampuan menghasilkan air susu pada kondisi lingkungan dan pakan yang terbatas. Seleksi keunggulan genetik melalui identifikasi suatu sifat yang diduga mempunyai hubungan kuat dengan sifat produksi, merupakan cara praktis guna mendukung program perbaikan genetik domba lokal di lapangan.

\section{MATERI DAN METODE}

\section{Tempat dan Waktu}

Penelitian ini dilaksanakan di areal padang penggembalaan Unit Pendidikan, Penelitian dan Peternakan Jonggol Institut Pertanian Bogor (UP3JIPB) Desa Singasari Kecamatan Jonggol Kabupaten Bogor dari bulan Juni sampai dengan November 2007.

\section{Bahan dan Alat}

Materi penelitian 100 ekor induk domba ekor tipis jawa umur 3-5 tahun yang dipelihara di padang penggembalaan dalam kondisi buting dan laktasi. Peralatan yang diperlukan dalam penelitian kandang koloni induk yang sedang melahirkan, kandang koloni induk, kandang koloni anak, kalung nomor dan timbangan ternak merk Shalter.

\section{Pendataan dan Identifikasi Domba Penelitian}

Ternak domba umur 3-5 tahun dalam keadaan bunting dipilih sebanyak 100 ekor dan diberi tanda berupa nomor kalung, kemudian ditempatkan pada kandang kelompok. Pemilihan ternak bunting dilakukan pagi hari, saat dimana kondisi rumen tidak dipenuhi oleh pakan. Untuk mengetahui kriteria induk bunting dilakukan dengan mengamati besarnya tubuh sebelah kanan atau mengamati dan meraba ambing. Sistem pemeliharaan domba digembalakan secara bebas di padang penggembalaan mulai pukul 09.00 sampai dengan pukul 16.00 dan sore harinya ternak dimasukan ke dalam kandang. 


\section{Pengamatan}

Peubah yang diamati dalam penelitian ini adalah produksi susu induk, pertambahan bobot badan, bobot sapih dan daya hidup anak domba periode prasapih berdasarkan jenis kelamin (jantan dan betina). Produksi susu induk diukur dengan cara memisahkan anak-anak domba, kemudian sebelum dan sesudah anak menyusu pada induk, terlebih dahulu dilakukan penimbangan masingmasing anak (Caja et al., 2006). Total selisih bobot anak domba sebelum dan sesudah menyusu tersebut merupakan jumlah produksi susu induk. Pengukuran dilakukan pukul 23.00, 05.00, 11.00 dan 17.00 (satuan dalam gram). Produksi susu diukur setiap tiga hari sekali.

\section{Analisis Statistik}

Pengaruh produksi susu terhadap bobot lahir dan bobot sapih diuji dengan analisis ragam dengan menggunakan general linier model (GLM) program statistica, apabila menunjukkan pengaruh yang nyata dilanjutkan dengan uji beda Duncan. Data ditampilkan sebagai rata-rata \pm standar deviasi (SD). Produksi susu dikelompokan menjadi tiga kelas produksi berdasarkan kelas produksi rendah $(\leq 300 \mathrm{~g} / \mathrm{ekor} / \mathrm{hari})$, sedang (300500 g/ekor/hari) dan tinggi (>500 g/ekor/hari).

\section{HASIL DAN PEMBAHASAN}

\section{Pertambahan Bobot Badan Anak domba}

Berdasarkan jumlah pengamatan sebanyak 94 ekor anak domba ekor tipis jawa, didapatkan rata-rata pertambahan bobot badan anak domba periode lahir sampai sapih umur 60 hari sebesar 60,26 \pm 24,79 g/ekor/hari dengan koefisien keragaman 41,15\%. Hasil penelitian ini lebih rendah dibanding dengan rataan pertambahan bobot badan domba Garut sebesar 67,75 g/ekor/hari (Subandriyo, 1984) dan domba Garut 70,45 g/ekor/hari (Dudi, 2003). Rendahnya pertambahan bobot badan pada domba ekor tipis jawa di UP3J disebabkan oleh perbedaan genetik dan pengaruh musim. Rata-rata pertambahan bobot badan anak domba garut di UPTD Margawati Garut selama musim kemarau sebesar 68,55 g/ekor/hari sedangkan pada musim hujan sebesar 71,97 g/eor/hari (Dudi, 2003) dan rataan pertambahan bobot badan domba ekor gemuk di Palu sebesar 100,35 g/ekor/ hari pada musim hujan, sedangkan pada musim kemarau 76,19 g/ekor/hari (Malewa, 2007). Musim kering dapat berpengaruh terhadap penurunan produksi dan komposisi hijauan terhadap produksi dan kualitas susu induk (Nudda et al., 2004 ).

Tabel 1 menunjukan pertambahan bobot badan anak domba periode lahir sampai sapih sangat nyata dipengaruhi oleh produksi susu induk $(p<0,01)$. Anak domba yang dilahirkan oleh induk dengan produksi susu diatas 500 g/ekor/hari, rata-rata pertambahan bobot badan sebesar 75,02 g/ekor/hari, sedangkan induk dengan produksi susu sedang dan rendah pertambahan bobot badan anak sebesar 58,48 g/ekor/hari dan 42,04 g/ekor/hari atau 
Tabel 1 Rataan dan setandar deviasi pertambahan bobot badan (g/ekor/hari) berdasarkan produksi susu dan jenis kelamin

\begin{tabular}{|c|c|c|c|c|}
\hline \multirow{2}{*}{$\begin{array}{l}\text { Produksi } \\
\text { (g/ekor/hari) }\end{array}$} & \multirow[t]{2}{*}{ susu } & \multicolumn{2}{|c|}{ Pertambahan bobot badan (g/ekor/hari) } & \multirow{2}{*}{ rataan } \\
\hline & & Jantan & Betina & \\
\hline$\leq 300$ & & $43,00 \pm 23,43$ & $41,21 \pm 20,97$ & $42,04 \pm \pm 21,36$ \\
\hline $300-500$ & & $62,57 \pm 22,74$ & $54,68 \pm 19,48$ & $58,48^{a} \pm 21.29$ \\
\hline$>500$ & & $77,06 \pm 28,25$ & $71,39 \pm 22,47$ & $75,02^{\mathrm{b}} \pm 25,98$ \\
\hline rataan & & $64,51 \pm 26,64$ & $55,63 \pm 21,99$ & $60,26 \pm 24,79$ \\
\hline
\end{tabular}

Keterangan: superskriyang berbeda kolom yang sama menunjukkan perbedaan sangat nyata $(\mathrm{p}<0.01)$ antar perlakuan

mengalami kenaikan pertambahan bobot badan anak sebesar 28,3\% dari induk dengan produksi susu sedang dan $78,5 \%$ dari induk produksi tinggi.

Menurut Hernandez dan Hohenboken (1980), antara produksi susu dengan pertambahan bobot badan domba memiliki korelasi sebesar 0.64 pada kelahiran tunggal dan 0,55 kelahiran kembar, dimana setiap kenaikan 1 liter produksi susu akan meningkatkan pertambahan bobot badan sebesar 110 gram dan 70 gram terhadap anak yang lahir tunggal dan kembar. Snowder dan Glimp (1991) melaporkan adanya hubungan korelasi yang nyata antara produksi susu dengan pertambahan bobot badan periode lahir sampai anak domba berumur 56 hari. Greenwood et al. (2004), melaporkan anak domba bangsa Suffolk yang diberi perlakuan dengan pemberian air susu ad libitum mengasilkan rata-rata pertambahan bobot badan sebesar 337 g/ekor/hari, sedangkan pemberian air susu yang dibatasi hanya menghasilkan pertambahan bobot badan sebesar 150 g/ekor/hari. Selanjutnya menurut Greenwood et al. (2004) anak domba tersebut setelah dipotong, menghasilkan bobot organ-organ tubuh anak domba yang mendapat air susu ad libitum seperti pankreas, hati, jantung, ginjal, testis,saluran pencernaan yang sangat nyata lebih berat.

Air susu merupakan nutrisi utama yang dibutuhkan anak domba untuk kekebalan tubuh dan pertumbuhan anak domba periode lahir sampai anak domba mampu mengkonsumsi dan mencerna pakan berupa padatan dan rumput (Pulina dan Nudda, 2004). Konsumsi air susu yang rendah selama 3-4 minggu setelah melahirkan akan menurunkan pertambahan bobot badan dan ukuran rangkah tubuh dan dapat menurunkan diameter serat otot daging pada domba (Stickland et al., 2004).

\section{Bobot Sapih Umur Dua Bulan}

Berdasarkan jumlah pengamat 94 ekor diperoleh rataan bobot sapih umur 8 minggu sebesar $5,67 \pm 1,81 \mathrm{~kg}$ dengan koefisien keragaman 32,13\%. Hasil penelitian ini lebih rendah dibanding dengan rata-rata bobot sapih umur 12 minggu anak domba ekor tipis jawa, domba ekor gemuk dan domba ekor tipis Sumatera masing-masing sebesar 9,2, 9,04 dan 11,4 kg/ekor (Setiadi dan Inigues, 1993). Rataan bobot sapih anak 
Tabel 2. Rataan dan setandar deviasi bobot sapih $(\mathrm{kg})$ berdasarkan produksi susu induk dan jenis kelamin di UP3J

\begin{tabular}{|c|c|c|c|c|}
\hline \multirow{2}{*}{$\begin{array}{l}\text { Produksi } \\
\text { (g/ekor/hari) }\end{array}$} & \multirow[t]{2}{*}{ susu } & \multicolumn{2}{|c|}{ Bobot sapih (kg) } & \multirow{2}{*}{ rataan } \\
\hline & & Jantan & betina & \\
\hline$\leq 300$ & & $4,83 \pm 1,94$ & $4,19 \pm 1,59$ & $4,49^{a} \pm 1,73$ \\
\hline $300-500$ & & $5,74 \pm 1,62$ & $5,18 \pm 1,34$ & $5,45^{a} \pm 1,49$ \\
\hline$>500$ & & $7,07 \pm 2,15$ & $6,36 \pm 1,55$ & $6,82^{\mathrm{b}} \pm 1,95$ \\
\hline rataan & & $6,04 \pm 1,97$ & $5,24 \pm 1,55$ & $5.66 \pm 1,82$ \\
\hline
\end{tabular}

Keterangan : superskrip yang berbeda pada kolom yang sama menunjukkan perbedaan sangat nyata $(p<0.01)$ antar perlakuan

domba Garut sebesar 10,62 kg (Tiesnamurti, 2002) dan bobot sapih anak domba hasil persilangan domba Sumatera dan St. Croix sebesar 9,5 kg (Doloksaribu et al., 2000). Malewa (2007) mendapatkan rataan bobot badan domba ekor gemuk umur 8 minggu di Kabupaten Palu Timur, Palu Selatan dan Biromaru masing-masing $7,7,7,58$ dan $8,16 \mathrm{~kg}$.

Faktor genetik dan lingkungan sangat besar pengaruhnya terhadap bobot sapih. Secara genetik domba ekor tipis jawa memiliki ukuran tubuh yang lebih kecil dibanding dengan domba ekor gemuk, domba Priangan dan domba - domba persilangan.

Produksi susu induk sangat nyata berpengaruh terhadap bobot sapih anak domba ekor tipis Jawa di UP3J $(p<0,01)$. Rataan bobot sapih anak domba yang dilahirkan dari induk yang memiliki produksi tinggi sebesar $6,82 \pm 1,95 \mathrm{~kg}$ sangat nyata lebih tinggi dari bobot sapih anak domba yang dilahirkan dari kelompok induk yang memiliki produksi susu rendah dan sedang yaitu masing-masing 4,49 $\pm 1,73$ dan 5,45 $\pm 1,49 \mathrm{~kg}$ (Tabel 2).

Air susu merupakan satusatunya nutrisi yang sangat penting yang dibutuhkan pertumbuhan anak domba terutama selama anak domba belum mampu makan rumput. Pengamatan di lapangan menunjukan bahwa selama periode lahir sampai sapih umur delapan minggu anak domba masih menggantungkan sumber makanan dari susu induk, meskipun sebagian besar sudah mulai belajar memakan rumput.

\section{Daya Hidup Anak Domba Periode Lahir Sampai Sapih}

Berdasarkan jumlah pengamatan 94 kelahiran didapatkan rataan daya hidup anak periode lahir sampai sapih sebesar $82,46 \pm 38,20 \%$ dengan koefisien keragaman 46,32\%. Hasil penelitian ini lebih tinggi dari domba garut sebesar 78,47\% (Nafiu, 2003), tetapi masih lebih rendah dari domba Sumatera dan hasil persilangannya dengan domba St. Croix dan Barbados Blackelly (domba komposit) pada generasi kedua yang mencapai 81,1\% (Doloksaribu et al., 2000).

Domba ekor tipis jawa memiliki daya hidup yang lebih baik terhadap lingkungan yang panas dibanding dengan domba Priangan. Keadaan ini dapat disadari bahwa domba ekor tipis Jawa di UP3J yang ada saat ini telah 
mengalami adaptasi yang cukup lama dan secara alami telah mengalami seleksi. Ukuran tubuh domba lokal yang relatif kecil dengan kebutuhan pakan yang lebih sedikit memungkinkan untuk hidup pada kondisi padang pengembalaan yang jelek. Pada negara tropis yang sebagian besar pemeliharaan dilakukan di pastura cenderung melakukan seleksi pada ternak yang memiliki ukuran tubuh sedang, karena ternak tersebut biasanya lebih agresif dan tahan hidup di lahan pastura (Piper and Ruvinsky, 2005). Tingginya daya hidup domba ekor tipis Jawa di UP3J juga disebabkan oleh jumlah anak sekelahiran yang rendah. Fogarty et al. (1984) melaporkan pada musim panas saat dimana jumlah anak sekelahiran rendah, persentasi hidup anak domba bangsa Finnsheep periode lahir sampai sapih justru lebih tinggi dibanding dengan bangsa domba yang memiliki jumlah kelahiran lebih banyak.

Daya hidup yang lebih tinggi pada domba komposit di Sumatera lebih disebabkan oleh efek heterosis hasil persilangan dan manajemen pemberian pakan yang lebih baik. Hasil persilangan antar bangsa domba dapat meningkatkan frekuensi gen heterosigot dan menurunkan gen homozigot resesif, dimana efek heterozigositas akan meningkatkan vigor sehingga kemampuan hidup lebih tinggi (Piper and Ruvinsky, 2005).

Angka kematian anak domba paling tinggi umumnya terjadi pada hari pertama sampai hari ketiga setelah dilahirkan, dengan angka kematian sebesar $5-30 \%$ di dalam populasi (Hincks dan Dodds, 2008).
Tabel 3 menunjukkan bahwa daya hidup sangat nyata dipengaruhi oleh produksi susu induk dan jenis kelamin $(\mathrm{p}<0,01)$. Rataan daya hidup pada anak yang dilahirkan dari induk dengan produksi rendah ( $\leq 300 \mathrm{~g} / \mathrm{h}), 300-500$ $\mathrm{g} / \mathrm{h}$ dan $\geq 500 \mathrm{~g} / \mathrm{h}$ masing - masing sebesar 33,33, 69,53 dan 96,77\%, sedangkan rata-rata daya hidup domba jantan dan betina masing-masing sebesar 94, 23 dan 72, 58\%.

Rendahnya daya hidup pada anak yang dilahirkan dari induk dengan produksi susu rendah disebabkan anak domba dalam mendapatkan kolustrum dan air susu induk selama periode lahir sampai sapih kebutuhan tidak mencukupi, sehingga vigoritas anak domba menjadi rendah. Daya hidup domba jantan yang tinggi disebabkan oleh rata-rata bobot lahir yang tinggi dan secara genetik ternak jantan lebih bersifat superior dan lebih dalam mendapatkan air susu induk.

Anak domba jantan lebih kuat dan lebih aktif (agresif) untuk mendapatkan kolustrum dan air susu induk selama saluran pencernaan belum mampu mencerna pakan berupa padatan, yaitu sekitar 3-4 minggu (Johnston, 1983). Anak domba jantan lebih cepat berdiri untuk mendapatkan kolustrum dan air susu induknya. Kolustrum dan air susu merupakan zat makanan yang sangat penting untuk kelangsungan hidup ternak domba yang baru dilahirkan sampai umur sapih, dan secara alami kolustrum merupakan sumber makanan yang tidak dapat digantikan dengan sumber makanan lain (Pulina dan Nudda 2004). Selain digunakan sebagai sumber makanan, kolustrum juga berfungsi 
Tabel 3 Rataan dan standar deviasi daya hidup (\%) berdasarkan tipe kelahiran dan jenis kelamin.

\begin{tabular}{|c|c|c|c|c|}
\hline \multirow{2}{*}{$\begin{array}{l}\text { Produksi } \\
\text { (g/ekor/hari) }\end{array}$} & \multirow[t]{2}{*}{ susu } & \multicolumn{2}{|l|}{ Daya hidup (\%) } & \multirow[t]{2}{*}{ Rataan } \\
\hline & & jantan & betina & \\
\hline$\leq 300$ & & $33,33 \pm 57,73$ & $33,33 \pm 57,73$ & $33,33^{a} \pm 51,64$ \\
\hline $300-500$ & & $94,74 \pm 22,1,60$ & $51,85 \pm 50,92$ & $69,57^{a} \pm 46,52$ \\
\hline$>500$ & & $100 \pm 0,00$ & $93,75 \pm 24,59$ & $96,77^{b} \pm 17,81$ \\
\hline rataan & & $94,23 \pm 23,54$ & $72,58 \pm 44,97$ & $82,46 \pm 38,20$ \\
\hline
\end{tabular}

Keterangan : superskrip yang berbeda pada kolom yang sama menunjukkan perbedaan sangat nyata $(\mathrm{p}<0,01)$ antar perlakuan

untuk mengeluarkan sisa kotoran (racun) dalam saluran pencernaan (laxative) dan merupakan zat yang dibutuhkan pada sistem kekebalan tubuh (Brandano et al., 2004).

Menurut Manalu (1999), pada ruminansia kolustrum merupakan alat angkut satu-satunya immunoglobin terutama IgG dari induk ke anak yang baru dilahirkan. Air susu merupakan substansi kompleks yang mengandung zat-zat seperti lemak, protein, komponen non protein, mineral dan vitamin yang sangat dibutuhkan untuk pertumbuhan dan daya hidup anak domba periode lahir sampai sapih. Air susu mengandung lisozim, laktoperoksidase, protein pengikat besi lakktoferin dan protein pengikat vitamin B12 dan folat yang secara langsung dibutuhkan aktivitas bakteri dalam saluran pencernaan serta digunakan sebagai antibodi (Manalu, 1999). Kemampuan untuk mendapatkan kolustrum sesaat setelah lahir atau paling lambat 18-36 jam menjadi faktor yang sangat menentukan untuk kelangsungan hidup anak domba, dimana pada saat yang bersamaan merupakan proses pembentukan terjalinnya hubungan anak dan induk domba (Brandano et al.,
2004). Kolustrum merupakan zat yang dihasilkan pertama kali oleh kelenjar susu dan umumnya diproduksi sebelum fase kelahiran hingga 5-6 hari setelah induk melahirkan.

Daya hidup anak domba dapat ditingkatkan dengan perbaikan pemberian pakan dan perawatan selama induk bunting, terutama fase tengah dan akhir kebuntingan (Subandriyo et al., 1994). Hasil penelitian Hincks dan Dodds (2008) menunjukan bahwa induk-induk domba yang memiliki bobot badan yang lebih tinggi pada fase tengah kebuntingan sangat nyata menghasilkan total bobot lahir dan daya hidup sampai umur sapih lebih tinggi. Seleksi terhadap sifat keindukan (mothering ability) dan tingkah laku anak domba juga dapat meningkatkan daya hidup anak domba, karena kemampuan atau tingkah laku induk dalam menerima anak sesaat setelah melahirkan sangat diperlukan untuk proses pembentukan kecepatan hubungan/ikatan dengan anaknya, sehingga anak domba yang baru lahir dapat memperoleh colostrum dan zat gizi yang cukup (Brandano et al., 2004).. Sifat keindukan dipengaruhi oleh beberapa faktor seperti faktor genetik, 
pengalaman induk, nutrisi selama fase kebuntingan, bangsa domba, suhu lingkungan dan tingkah laku anak domba (Dwyer, 2008). Selanjutnya menurut Dwyer (2008), meskipun faktor genetik merupakan faktor yang paling dominan dalam menentukan sifat keindukan, pemberian estradiol pada akhir fase kebuntingan dapat meningkatkan sifat keindukan pada induk domba Scottish Blackface dan Suffolk.

\section{SIMPULAN}

Produksi susu induk berpengaruh sangat nyata terhadap pertambahan bobot badan, bobot sapih dan daya hidup anak domba ekor tipis Jawa periode lahir sampai sapih yang dipelihara di padang penggembalaan Unit Pendidikan dan penelitian Peternakan Jonggol (UP3J). Produksi susu induk diatas 500 g/hari akan meningkatkan pertambahan bobot badan, bobot sapih dan daya hidup anak domba jantan maupun betina periode lahir sampai sapih umur dua bulan. Pertambahan bobot badan dan bobot sapih anak domba jantan lebih tinggi dibanding betina, karena anak domba jantan memiliki sifat lebih aktif dan agresif sesaat setelah proses kelahiran untuk menyusui induk guna mendapatkan kolustrum.

\section{DAFTAR PUSTAKA}

Brandano, P, S.P.G Rassu dan Lanza. 2004. Feeding Dairy Lamb. In:
Pullina, G, editor. Dairy Sheep Nutrition. CABI Publishing.

Caja, G, A. A. K. Salama dan X. Such. 2006. Omitting the dry off period negatively affects colostrums and milk yield in dairy goat. J Dairy Sci 89:4220-28.

Doloksaribu, M, R.M. Gatenby, G.E. Bradford. 2000. Comparison of sumatera sheep and hair sheep crossbreeds, bagian III: Reproductive performance of F2 ewes weights of lambs. Small Rum Res 28: 115-121.

Dudi. 2003. Pendugaan nilai pemuliaan bobot badan prasapih domba priangan yang menggunakan model dirrect additive genetic effect, maternal genetic effect dan lingkungan bersama serta model catatan berulang [Tesis]. Bogor: Program Pascasarjana, Institut Pertanian Bogor.

Dwyer, C. M. 2008. Genetic and physiological determinants of maternal behavior and lamb survival: Implications for lowimput management [Abstract]. J Anim Sci 86:246-58.

Fogarty, N. M, G.E. Dickerson and L.D. Young. 1984. Lamb production and its components in pure breed and komposdite lines. I: Seasonal and other enviromental effects. J Anim Sci 58:258-300.

Food and Agriculture Organization (FAO). 2002. Conserving and Developing Farm Animal Diversity. Rome: Secretariat of The Report on The State of The Word's Animal Genetic Resources. FAO. Roma.

Greenwood, P. L, A.S. Hunt and A.W. Bell. 2004. Effects birth weight and postnatal nutrition on neonatal 
sheep: IV. Organ growth. J Anim Sci 82:422-28.

Hernandez, G.H and W. Honenboken. 1980. Relationships between ewe milk production and composition and preweaning lamb weight gain. J Anim Sci 50:597-603.

Hincks, J.M.E and K.G Dodds. 2008. Management of maternal-offspring behavior to improve lamb survival in easy care sheep systems. J Anim Sci 86:259-70.

Iniquez, L, M. Sancez and S.P. Ginting. 1991. Productivity in sumantran sheep in a system integrated with with rubber plantation. Small ruminant Colaborative Research Support Program. Annual Report 5:303-17.

Johnston, R.G. 1983. Introduction to Sheep Farming. Granada Publishing, London.

Manalu, W. 1999. Fisiologi Laktasi [Diktat Kuliah]. Bogor: Program Pascasarjana, Bogor: Program Pasca Sarjana Fakultas Kedokteran Hewan, Institut Pertanian Bogor.

Nafiu, L. 2003. Evaluasi genetik domba priangan dan persilangannya dengan st. croix dan moulton charollais [Disertasi]. Bogor: Program Pascasarjana, Institut Pertanian Bogor.

Nudda, A, G. Battacone, R. Bencini and G. Pulina. 2004. Nutrition and Milk Quality. In: Pulina, G, editor. Dairy Sheep Nutritionl. CABI Publishing.

Piper, L and A. Ruvinsky. 2005. The Genetics of Cattle. CAB International.

Pulina G and A. Nudda, 2004. Milk Production. In: Pullina, G, editor.
Dairy Sheep Nutrition. CABI Publishing.

Setiadi, B and L. Inigues. 1993. Reproduction performance of small ruminants in an on-farm research program with village farm in west java. Small Rum Res 12:280-91.

Snowder, G.D and H.A. Glim. 1991. Influence breed, number of sukling lambs, and stage lactation on ewes milk production and lamb growth under range conditions. I Anim Sci 69:923-30.

Subandriyo. 1984. Factor a affecting survival of range sheep in the U.S, and characterization of sheep in Indonesian [Tesis]. Montana, Montana State University, Bozman.

Subandriyo, B. Setiadi, T.D. Soedjana dan P. Sitorus. 1994. Produktivitas usaha ternak domba di pedesaan. Bogor: Pusat Penelitian dan Pengembangan Peternakan. Badan Penelitian dan Pengembangan Pertanian. Deptan.

Sticland, N.C, S. Bayol, C. Asthon and C. Rehfeldt. 2004. Manipulation of Muscle Fibre Number during Prenatal Development. In: Everts, M.E, M.W.F.tePas and H.P. Haagsmant, editor. Muscle Development of Livestock, Animal Fisiology, Genetic and Meat Quality. CABI Publishing.

Tiesnamurti, B. 2002. Kajian genetik terhadap induk domba priangan peridi ditinjau dari aspek kuantitatif dan molekuler [Disertasi]. Bogor: Program Pascasarjana, Institut Pertanian Bogor. 